\title{
PENGARUH PEMANFAATAN SISTEM INFORMASI AKADEMIK (AIS) TERHADAP KINERJA INDIVIDUAL DENGAN KEMUDAHAN PENGGUNA SEBAGAI VARIABEL MODERATOR
}

\author{
Rahmat Rizkiyanto
}

\author{
Lembaga Penerbangan dan Antariksa Nasional (LAPAN)
}

\begin{abstract}
Effect of The Use Academic Information System On The Individual's Performance With Ease as Moderating Variable.This research purpose to determine whether the existing Information Systems (AIS), which in this case is a AIS affects individuals performance is moderated by the ease of use. Research instrument in this study is a questionnaire with variables measuring based on a Likert scale. Questionnaire was tested with reliability and validity test. Then the classical assumption test questionnaire covering normality test and Multicolinearity Test. Absolute value difference test was conducted to test the hypothesis. From the results of tests performed, showed that the variable of use of AIS give significant positive effect on the performance of the individual. The variable of ease of use did not moderate the effect of the use of the AIS on the performance of the individual, so it can be said that ease of use is not a variable moderating.
\end{abstract}

Keywords: academic information system, individual performance, ease

\begin{abstract}
Abstrak. Pengaruh Pemanfaatan Sistem Informasi Akademik (AIS) Terhadap Kinerja Individual Dengan Kemudahan Pengguna Sebagai Variabel Moderator. Penelitian ini bertujuan untuk mengetahui apakah Sistem Informasi akademik mempengaruhi kinerja individual dengan dimoderasi oleh kemudahan pengguna. Instrumen penelitian dalam penelitian ini adalah kuisioner dengan pengukuran variabel yang mangacu pada skala Likert. Kuisioner diuji dengan uji reliabilitas dan uji validitas. Kemudian pada kuisioner dilakukan uji asumsi klasik yang meliputi uji normalitas dan uji multikolineritas. Uji selisih nilai mutlak dilakukan untuk menguji hipotesis. Dari hasil pengujian yang dilakukan, didapatkan hasil bahwa variabel pemanfaatan Academic Information System AIS berpengaruh positif dan signifikan terhadap kinerja individual. Namun variabel kemudahan penggunaan ternyata tidak memoderasi pengaruh pemanfaatan Academic Information System AIS terhadap kinerja individual, sehingga dapat dikatakan bahwa variabel kemudahan penggunaan bukanlah variabel moderator.
\end{abstract}

Kata Kunci: sistem informasi akademik, kinerja individual, kemudahan 


\section{PENDAHULUAN}

Penerapan teknologi dalam berbagai bidang di dalam kehidupan manusia merupakan sebuah hal yang tidak terelakkan lagi. Tidak hanya itu, teknologi bahkan dapat dikatakan telah menjadi sebuah kebutuhan. Adanya teknologi yang mutakhir, akan memberikan respon dan pengaruh kepada pengguna teknologi tersebut. Seperti halnya pada sebuah aplikasi. Penerapannya akan memberikan respon dan pengaruh yang pada akhirnya respon dan pengaruh tersebut adalah menunjukkan tingkat kepuasan serta perilaku pengguna terhadap aplikasi tersebut.

Teknologi informasi dapat didefinisikan sebagai perpaduan antara teknologi komputer dan telekomunikasi dengan teknologi lainnya seperti perangkat keras, perangkat lunak, database, teknologi jaringan, dan peralatan telekomunikasi lainnya (Maharsi 2000). Selanjutnya, teknologi informasi dipakai dalam sistem informasi organisasi untuk menyediakan informasi bagi para pemakai dalam rangka pengambilan keputusan. Bagi lembaga perguruan tinggi teknologi sistem informasi telah menjadi kebutuhan untuk menunjang proses pendidikan. Pemanfaatan teknologi informasi ini sangat dibutuhkan untuk meningkatkan efisiensi dan produktivitas bagi manajemen pendidikan di perguruan tinggi.

Menurut Davis (1986) dalam teori Technology Acceptance Model (TAM) dijelaskan bahwa persepsi pengguna akan menentukan sikapnya dalam kemanfaatan penggunaan TI. Dalam TAM digambarkan bahwa penerimaan penggunaan TI dipengaruhi oleh kemanfaatan (usefulness) dan kemudahan pengguna (ease of use). Kemanfaatan dan kemudahan pengguna mempunyai pengaruh ke minat perilaku. Pemakai teknologi akan mempunyai minat menggunakan teknologi (minat perilaku) jika merasa sistem teknologi bermanfaat dan mudah digunakan. Pemakai sistem informasi akan lebih banyak memanfaatkan sistem jika sistem informasi tersebut mudah digunakan. Sebaliknya jika sistem informasi tidak mudah digunakan (rumit) pemakai akan lebih sedikit dalam memanfaatkan sistem informasi tersebut. 
Sistem Informasi Akademik Universitas Islam Negeri Syarif Hidayatullah Jakarta atau yang lebih dikenal dengan nama "AIS" adalah sebuah sistem informasi berbasis web yang dibangun dengan tujuan untuk pengorganisasian data akademik UIN Syarif Hidayatullah Jakarta secara online. AIS (Academic Information System) saat ini telah mencakup berbagai modul, diantaranya adalah modul perkuliahan, absensi, penjadwalan, dosen pembimbing akademik, keuangan, statistic, dan sebagainya.Beberapa fasilitas yang disediakan oleh Sistem Informasi Akademik (AIS) antara lain: informasi biodata mahasiswa, jadwal kuliah, informasi kemajuan hasil belajar mahasiswa, rekapitulasi nilai akademik, tugas mengajar dosen, serta statistik data lain. Selain itu AIS juga menyediakan fasilitas cetak untuk keperluan administrasi akademik yang dapat dipakai oleh seluruh admin baik dari tingkat universitas sampai program studi.

Untuk mengetahui keberhasilan sistem informasi akademik (AIS) tersebut membawa dampak positif dalam peningkatan kinerja individual maka dilakukan suatu penelitian yang berjudul "Kajian Pengaruh Penggunaan Sistem Informasi Akademik (AIS) Terhadap Kinerja Individual Dengan Kemudahan Penggunaan Sebagai Variabel Moderator".

Teknologi informasi telah membawa perubahan yang sangat mendasar bagi organisasi baik swasta maupun organisasi publik. Dengan adanya teknologi informasi pemrosesan data akan mengalami perubahan dari manual ke otomatisasi. Penelitian - penelitian tentang pemanfaatan teknologi informasi dan kinerja individual yang telah dilakukan di Indonesia menunjukkan hasil yang belum konsisten. Hal tersebut dibuktikan oleh penelitian Darwin (1999) dan Diana (2001) yang memberikan bukti empiris bahwa terdapat pengaruh positif pemanfaatan teknologi informasi terhadap kinerja individual. Di sisi lain, hasil penelitin Jurnali (2001) memberikan bukti empiris bahwa tidak ada pengaruh pemanfaatan teknologi informasi terhadap kinerja individual.

Penelitian Sunarta (2005) mengungkapkan tingkat pemanfaatan teknologi informasi di lingkungan sektor publik ditinjau dari intensitas atau frekuensi penggunaan dan jenis sofware yang dikuasai oleh pengguna memiliki 
pengaruh yang positif dalam memperbaiki atau meningkatkan kinerja individual. Penelitian Kurniawan (2008) membuktikan bahwa kemanfaatan teknologi informasi memiliki pengaruh positif yang signifikan atas kepuasan pemakai teknologi informasi tersebut, akan tetapi kemanfaatan teknologi informasi memberikan pengaruh positif yang tidak signifikan terhadap kinerja individu pekerja, dan kepuasan pemakai tidak secara signifikan memberikan pengaruh positif pada kinerja pekerja.

Berdasarkan uraian di atas yang menjadi pertanyaan dalam penelitian ini adalah: pertama, apakah pemanfaatan Sistem Informasi Akademik (AIS) berpengaruh terhadap kinerja individual? Kedua, Apakah kemudahan penggunaanan Sistem Informasi Akademik (AIS) memoderasi hubungan antara pemanfaatan AIS dengan kinerja individual?

\section{METODE}

Berdasarkan kerangka pemikiran teoritis, dapat disusun konsep penelitian untuk melihat hubungan antar variabel. Ruang lingkup penelitian dilakukan di lingkungan Universitas Islam Negeri Syarif Hidayatullah Jakarta dengan lama penelitian 5 bulan. Teknik sampling yang digunakan di dalam penelitian ini adalah random sampling. Random sampling merupakan teknik sampling probabilitas yang bersifat sederhana, dimana setiap sampel yang berukuran sama memiliki probabilitas atau kesempatan yang sama untuk terpilih dari sebuah populasi.

Alasan penggunaan random sampling adalah data populasi yang akan diukur homogen. Penelitian ini tidak mengkategorikan pengukuran berdasarkan fakultas, jenis kelamin dan sebagainya. Oleh karena itu, kesempatan setiap mahasiswa untuk terpilih sebagai sampel adalah sama maka penulis menggunakan teknik random sampling. Jumlah total populasi dosen dan pegawai di UIN Syarif Hidayatullah Jakarta yang mempunyai akun AIS berjumlah 2748 orang sehingga perhitungan minimum sampel yang dibutuhkan adalah 97 orang.

Dalam penelitian ini terdapat 3 jenis variabel yang terdiri dari variabel independen, variabel dependen dan variabel moderating. Variabel independen adalah tipe variabel yang menjelaskan atau mempengaruhi variabel yang 
lain. Variabel I ndependen dalam penelitian ini adalah pemanfaatan Academic Information System (AIS) (Utilization). Sedangkan Variabel dependen adalah tipe variabel yang dijelaskan atau dipengaruhi oleh variabel independen.

Variabel dependen dalam penelitian ini adalah kinerja individual (individual impact). Variabel moderating adalah variabel yang memperkuat atau memperlemah hubungan langsung antara variabel independen dan variabel dependen. Variabel moderating dalam penelitian ini adalah kemudahan penggunaanan (ease of use).

Pemanfaatan sistem informasi berhubungan dengan perilaku menggunakan sistem informasi tersebut untuk menyelesaikan tugas. Pengukurannya seperti frekuensi penggunaan atau diversifikasi program aplikasi yang digunakan (Thompson, et al 1991). Variabel pemanfaatan (Utilization) sistem informasi menggunakan instrumen yang dikembangkan oleh Thompson, et al (1991). Tiga indikator dari konstruk pemanfaatan Academic Information System (AIS) terdiri dari : pertama, intensitas penggunaan AIS; kedua, frekuensi penggunaan AIS; ketiga, jumlah menu AIS yang digunakan.

Kinerja individual yang dimaksud adalah pencapaian serangkaian tugastugas individu dengan dukungan teknologi informasi yang ada (Goodhue dan Thompson, 1995). Pengukuran variabel kinerja individual menggunakan tiga indikator dari konstruk kinerja individual, yaitu : pertama, keefektifan pekerjaan dengan menggunakan AIS; Kedua, bantuan PUSTIPANDA terhadap pelaksanaan kinerja tugas; dan Ketiga, peningkatan produktifitas dengan menggunakan AIS. Instrumen ini dikembangkan oleh Goodhue dan Thompson (1995) dimana pengukurannya dengan menggunakan 5 skala likert, yaitu 1 berarti sangat tidak setuju, 2 berarti tidak setuju, 3 berarti netral, 4 berarti setuju dan 5 berarti sangat setuju. Jika nilai skala likert 1 dapat diartikan bahwa kinerja individualnya rendah. Sedangkan jika nilai skala likert 5 dapat diartikan bahwa kinerja individualnya tinggi.

Davis, (1989) mendefinisikan persepsi kemudahan penggunaanan sebagai "tingkat dimana seseorang percaya bahwa menggunakan sistem 
tertentu akan bebas dari usaha" yang mencerminkan bahwa usaha merupakan sumber daya yang terbatas bagi seseorang yang akan mengalokasikan untuk berbagai kegiatan. Variabel kemudahan penggunaanan diukur dengan instrumen yang dikembangkan oleh Davis, et al (1989) dan Chau, 1996 (dalam Jogiyanto 2007). Pengukuran tersebut menggunakan enam indikator yaitu: Pertama, Kemudahan pengaksesan AIS dari luar kampus. Kedua, kemudahan pengaksesan AIS melalui fasilitas kampus. Ketiga, AIS yang bersifat user friendly. Keempat, susunan menu AIS yang mudah dipahami. Kelima, hasil report AIS yang sesuai dengan kebutuhan. Keenam, Kemudahan penggunaanan AIS memperlancar pekerjaan. Instrumen kemudahan penggunaanan yang digunakan dalam penelitian ini diukur dengan lima poin skala Likert, yaitu 1 berarti sangat tidak setuju, 2 berarti tidak setuju, 3 berarti netral, 4 berarti setuju dan 5 berarti sangat setuju. Jika nilai skala likert 1 dapat diartikan bahwa sistem informasi tidak mudah (sulit) digunakan. Sedangkan jika nilai skala likert 5 dapat diartikan bahwa sistem informasi mudah digunakan.

Statistik Deskriptif memberikan gambaran tentang distribusi frekuensi variabel-variabel penelitian, nilai maksimum, nilai minimum, rata-rata, dan nilai standar deviasi. Uji kualitas data dilakukan dengan menguji validitas dan realibilitas data yang telah didapat. Uji validitas dan reliabilitas mutlak dilakukan, karena jika instrument yang digunakan sudah tidak valid dan reliable makan dipastikan hasil penelitiannya pun tidak akan valid dan reliabel. Sugiono (2007:137) menjelaskan perbedaan antara penelitian yang valid dan reliable dengan instrument yang valid dan reliable sebagai berikut: Pertama, Penelitian yang valid artinya bila terdapat kesamaan antara data yang terkumpul dengan data yang sesungguhnya terjadi pada objek yang diteliti. Kedua, Penelitian yang reliable bila terdapat kesamaan data dalam waktu yang berbeda

Uji validitas digunakan untuk mengukur sah atau valid tidaknya suatu kuesioner. Suatu kuesioner dikatakan valid jika pertanyaan pada kuesioner mempu untuk mengungkapkan sesuatu yang akan diukur oleh kuesioner tersebut. Pengujian validitas ini menggunakan Pearson Correlation yaitu dengan 
cara menghitung korelasi antara skor masing-masing butir pertanyaan dengan total skor. Jika korelasi antara skor masing-masing butir pertanyaan dengan total skor mempunyai tingkat signifikansi di bawah 0,05 maka butir pertanyaan tersebut dinyatakan valid dan sebaliknya (Ghozali, 2009).

Uji reliabilitas data adalah suatu uji yang dilakukan untuk mengukur suatu kuesioner yang merupakan indikator dari suatu variabel atau konstruk. Suatu kuesioner dikatakan reliable atau handal jika jawaban seseorang dalam kuesioner konsisten atau stabil dari waktu ke waktu. Suatu kuesioner dikatakan relaibel atau handal jika memberikan nilai Cronbach alpha di atas 0,6 (Ghozali, 2009:45).

Uji normalitas bertujuan untuk menguji apakah dalam model regresi dependen variabel dan independen variabel keduanya mempunyai distribusi normal ataukah tidak. Model regresi yang baik adalah memiliki distribusi data normal atau mendekati normal (Ghozali, 2006). Normalitas dapat dideteksi dengan melihat penyebaran data (titik) pada sumbu diagonal dari grafik normal P-P Plot. Dasar pengambilan keputusan: Pertama, jika data menyebar disekitar garis diagonal dan mengikuti arah garis diagonal, atau grafik histogramnya menunjukkan pola distribusi normal, maka regresi memenuhi asumsi normalitas. Kedua, jika data menyebar jauh dari garis diagonal dan atau tidak mengikuti arah garis diagonal, atau grafik histogram tidak menunjukkan pola distribusi normal, maka model regrasi tidak memenuhi asumsi normalitas.

Uji multikolineritas dilakukan untuk menguji apakah pada model regresi ditemukan adanya korelasi antar variabel independen. Model regresi yang baik seharusnya tidak terjadi korelasi diantara variabel independen. (Ghozali 2006). Pengujian ada tidaknya gejala multikolinearitas dilakukan dengan memperhatikan nilai matriks korelasi yang dihasilkan pada saat pengolahan data serta nilai VIF (Variance Inflation Factor) dan tolerance-nya. Jika nilai tolerance value dibawah 0,10 atau variance inflation factor diatas 10 maka terjadi multikolinearitas.

Teknik analisis yang digunakan adalah Uji Nilai Selisih Mutlak. Dilakukan uji ini karena menurut Furcot dan Shearon (dalam Ghozali 2006) interaksi 
seperti ini lebih disukai oleh karena ekspektasi sebelumnya berhubungan dengan kombinasi antara X1 dan X 2 dan berpengaruh terhadap Y. Persamaan Regresi dalam penelitian ini adalah :

$$
\mathrm{Y}=\mathrm{a}+\mathrm{b} 1 \mathrm{X} 1+\mathrm{b} 2 \mathrm{X} 2+\mathrm{b} 3|\mathrm{X} 1-\mathrm{X} 2|+\mathrm{e}
$$

Keterangan :

$\begin{array}{ll}\mathrm{a} & : \text { Konstanta } \\ \mathrm{Y} & : \text { Kinerja Individual } \\ \mathrm{X}_{1} & : \text { Pemanfaatan AIS } \\ \mathrm{X}_{2} & : \text { Kemudahan Penggunaan } \\ \mathrm{b}_{1}, \mathrm{~b}_{2}, \mathrm{~b}_{3} & : \text { Koefisien Regresi } \\ \mathrm{e} & : \text { error }\end{array}$

Uji koefisien determinasi dilakukan untuk mengetahui seberapa jauh kemampuan model dalam menerangkan variabel-variabel independen. Uji $\mathrm{F}$ digunakan untuk mengetahui ada tidaknya pengaruh secara bersama-sama (simultan) variabel independen (bebas) terhadap variabel dependen (terikat). Uji t dilakukan untuk mengetahui seberapa jauh pengaruh variabel independen menerangkan variabel dependen (Ghozali,2001). Apabila nilai probabilitas $<0,05$ maka hipotesis diterima. Namun apabila nilai probabilitas $>0,05$ maka hipotesis ditolak.

\section{PEMBAHASAN}

Jumlah sampel yang digunakan untuk penelitian ini adalah 97 sampel dengan data yang didapatkan dari kuisioner. Data-data ini kemudian diinputkan ke dalam aplikasi pengolah data untuk dilakukan perhitungan. Berikut adalah analisis frekuensi data sampel yang digunakan:

Variabel Pemanfaatan Academic Information System(AIS) mempunyai kisaran teoritis bobot jawaban antara 3 - 15 dengan rata-rata sebesar 9 . Sedangkan kisaran empiris bobot jawaban responden adalah antara $3-15$ dengan rata-rata jawaban sebesar 9,29 dan standar deviasi 2,850. Nilai rata-rata jawaban variabel pemanfaatan AIS hampir sama dengan rata-rata kisaran teoritis, hal ini mengindikasikan bahwa persepsi responden tentang pemanfaatan AIS adalah sedang. 
Bobot jawaban atas pertanyaan kinerja individual pada kisaran teoritis antara 3 - 15 dengan rata- rata sebesar 9. Sedangkan kisaran empiris atas bobot jawaban responden adalah 4 - 15 dengan rata-rata jawaban responden adalah sebesar 12,21 dan standar deviasi 2,136. Rata-rata empiris jawaban responden atas variabel kinerja individual diatas rata-rata teoritis, ini menggambarkan bahwa responden penelitian mempunyai persepsi kinerja individual relatif tinggi.

Bobot jawaban atas pertanyaan kemudahan penggunaan AIS pada kisaran teoritis antara 6 - 30 dengan rata-rata sebesar 18. Sedangkan kisaran empiris atas bobot jawaban responden adalah 8 - 30 dengan rata-rata empiris jawaban responden atas variabel kemudahan penggunaan AIS adalah sebesar 24,65 dan standart deviasi 4,186. Rata-rata empiris jawaban responden diatas rata-rata teoritis ini mengindikasikan bahwa responden mempunyai persepsi kemudahan penggunaan AIS relatif tinggi.

Kualitas data yang dihasilkan dari penggunaan instrumen penelitian dapat dievaluasi melalui uji reliabilitas dan validitas. Uji tersebut masingmasing untuk mengetahui konsistensi dan akurasi data yang dikumpulkan dari penggunaan instrumen. Untuk mengukur reliabilitas dengan uji statistik Cronbach alpha. Suatu konstruk atau variabel dikatakan reliabel jika memberikan nilai Cronbach alpha> 0,60 (Nunnaly, 1967 dalam Ghozali 2006). Terlihat bahwa nilai Cronbach alpha untuk variabel pemanfaatan AIS sebesar 0,704 yang berarti 0,704 $>0,60$. Hasil tersebut menunjukkan bahwa semua pertanyaan mengenai variabel pemanfaatan AIS adalah reliabel. Terlihat bahwa nilai Cronbach alpha untuk variabel kinerja individual sebesar 0,846 yang berarti $0,846>0,60$. Hasil tersebut menunjukkan bahwa semua pertanyaan mengenai variabel kinerja individual adalah reliabel. Terlihat bahwa nilai Cronbach alpha untuk variabel kemudahan penggunaan sebesar 0,837 yang berarti 0,837>0,60. Hasil tersebut menunjukkan bahwa semua pertanyaan mengenai variabel kemudahan penggunaan adalah reliabel.

Pengujian validitas ini menggunakan Pearson Correlation yaitu dengan cara menghitung korelasi antara skor masing-masing butir pertanyaan dengan 
total skor. Jika korelasi antara skor masing-masing butir pertanyaan dengan total skor mempunyai tingkat signifikansi di bawah 0,05 maka butir pertanyaan tersebut dinyatakan valid dan sebaliknya (Ghozali, 2009). Uji signifikansi dilakukan dengan membandingkan nilai $r$ hitung dengan $r$ tabel untuk degree of freedom $(\mathrm{df})=\mathrm{n}-2$, dalam hal ini $\mathrm{n}$ adalah jumlah sampel. Pada penelitian ini jumlah sampel $(n)=97$ dan besarnya $\mathrm{df}$ dapat dihitung $97-2=95$, dengan $\mathrm{df}=$ 95 dan alpha $=0,05$, didapat $r$ tabel $=0,199$. Untuk menguji apakah masingmasing indikator valid atau tidak dapat dilihat pada tampilan output Cronbach alpha pada kolom Correlated Item - Total Correlation baik pada konstruk.

Pemanfaatan AIS, kinerja individual dan kemudahan penggunaanan AIS. Kemudian nilai Correlated Item - Total Correlation dibandingkan dengan hasil perhitungan $r$ tabel $=0,199$, jika $r$ hitung $>r$ tabel dan bernilai positif maka butir atau pertanyaan tersebut dinyatakan valid. Dari data, dapat dilihat bahwa $r$ hitung Corrected Item - Total Correlation untuk indikator konstruk pemanfaatan AIS, kinerja individual, dan kemudahan penggunaan $>$ dari $r$ tabel yaitu sebesar 0,199. Dari hasil tersebut dapat disimpulkan bahwa semua indikator konstruk yang ada adalah valid.

Berdasarkan hasil, dapat dilihat tampilan grafik histogram maupun normal plot yang menggambarkan bahwa grafik histogram memberikan pola distribusi normal. Sedangkan pada grafik normal plot terlihat titik-titik menyebar disekitar garis diagonal serta penyebaran mnegikuti arah garis diagonal. Kedua grafik ini menunjukkan bahwa model regresi memenuhi uji normalitas.

Hasil perhitungan nilai tollerance menunjukkan tidak ada variabel independen yang memiliki tollerance kurang dari 0.10 yang berarti tidak ada korelasi antar variabel independen yang nilainya lebih dari 95\%. Hasil perhitungan nilai Variance Inflation Faktor (VIF) juga menunjukkan hal yang sama tidak ada satu variabel independen yang memiliki nilai VIF lebih dari 10. Jadi dapat disimpulkan bahwa tidak ada multikolinearitas antar variabel independen dalam model regresi. 
Tabel 1. Hasil Uji Multikolineritas

\begin{tabular}{llll}
\hline \multirow{2}{*}{ Variabel Independen } & \multicolumn{2}{c}{ Collinearity Statistics } & Keterangan \\
& Tollerance & VIF & \\
\hline Pemanfaatan AIS & 0,993 & 1,007 & Tidak ada multikolineritas \\
Kemudahan & 0,993 & 1,007 & Tidak ada multikolineritas \\
penggunaan & & & \\
\hline
\end{tabular}

Sumber : Data primer diolah, 2013

Berdasarkan hasil olahan data, menunjukkan bahwa nilai Adjusted $\mathrm{R}^{2}$ cukup tinggi yaitu sebesar 50,9\% yang berarti variabilitas Kinerja Individual yang dapat dijelaskan oleh variabel pemanfaatan AIS(Utilization), kemudahan penggunaan (EaseOfUse), dan moderating secara bersama-sama atau simultan mempengaruhi kinerja individual (Individual_Impact).

Hasil tampilan output ANOVA atau F test di atas menunjukkan bahwa nilai $F$ hitung sebesar 34.238 dengan tingkat signifikan 0,000 jauh di bawah 0,05 . Hal tersebut menunjukkan bahwa variabel independen pemanfaatan AIS (Utilization), kemudahan penggunaan (EaseOfUse), dan moderating secara bersama-sama atau simultan mempengaruhi kinerja individual (Individual_Impact).

Hasil tampilan output Coefficient di atas menunjukkan bahwa secara individu variabel Penggunaan AIS (Utilization) memberikan nilai koefisien 0,437 dengan probabilitas signifikan 0,006. Variabel kemudahan penggunaan (EaseOfUse) memberikan nilai koefisien 1,422 dengan probabilitas signifikan 0,000. Kedua variabel ini dapat disimpulkan berpengaruh terhadap kinerja individual (Individual_Impact). Variabel moderating ternyata tidak signifikan yaitu dengan probabilitas signifikan 0,564 yang jauh di atas 0,05. Dengan kata lain, variabel moderating kemudahan penggunaan tidak berpengaruh secara signifikan terhadap pemanfaatan AIS dan kinerja Individual.

Hipotesis 1 menyatakan bahwa Pemanfaatan Academic Information System (AIS) berpengaruh positif terhadap kinerja individual. Pada tabel 4.24 dapat dilihat bahwa nilai t hitung variabel pemanfaatan AIS sebesar 2,786 sedangkan nilai t tabel pada tingkat signifikan 5\% dan $\mathrm{df}=95$ (97-2) sebesar 1,985 (merujuk pada tabel distribusi $t)$ sehingga $t$ hitung $>t$ tabel $(2,786>$ 
1,985). Untuk nilai signifikan yang dimiliki sebesar 0,006 yang berarti nilai tersebut lebih kecil dari 0,05. Hasil tersebut menunjukkan bahwa variabel Pemanfaatan Academic Information System (AIS) berpengaruh positif terhadap kinerja individual. Dari penjelasan tersebut, dapat disimpulkan hipotesis 1 yaitu Pemanfaataan Academic Information System (AIS) berpengaruh positif dan signifikan terhadap Kinerja Individual diterima.

Hipotesis 2 menyatakan Kemudahan penggunaanan Academic Information System (AIS) memoderasi pengaruh pemanfaatan AIS terhadap kinerja individual. Berdasarkan hasil pengujian, didapat nilai $t$ hitung untuk variabel moderating kemudahan penggunaan AIS terhadap kinerja individual mempunyai nilai sebesar 0,579. Variabel moderating ternyata tidak signifikan yaitu dengan probabilitas signifikan 0,564 yang jauh di atas 0,05. Dengan kata lain, variabel moderating kemudahan penggunaan tidak berpengaruh secara signifikan terhadap pemanfaatan AIS dan kinerja Individual. Dari data tersebut menunjukkan bahwa variabel kemudahan penggunaan bukan merupakan variabel moderating.

Hasil pengujian hipotesis 1 menunjukkan bahwa tingkat pemanfaatan Academic Information System (AIS) di lingkungan Universitas Islam Negeri (UIN) Syarif Hidayatullah Jakarta yang ditinjau dari intensitas pemakaian, frekuensi penggunaan dan jenis menu yang diakses memiliki pengaruh positif terhadap peningkatan kinerja individual. Hasil penelitian ini mendukung teori model Technology to Performance chain (TPC) bahwa teknologi sistem informasi berpengaruh terhadap kinerja pada tingkat individual. Agar teknologi sistem informasi memberikan dampak positif terhadap kinerja individual, maka teknologi sistem informasi tersebut harus dimanfaatkan dan harus sesuai dengan jenis pekerjaan yang dilakukan. Hasil pengujian hipotesis 1 penelitian ini mendukung Goodhue dan Thompson (1995), Darwin (1999), Diana (2001) dan Sunarta (2005) yang memberikan bukti empiris bahwa pemanfaatan teknologi informasi berpengaruh positif dan signifikan terhadap kinerja individual. Berdasarkan pengujian hipotesis 2 menunjukkan bahwa kemudahan penggunaan bukan merupakan variabel moderating yang dapat mempengaruhi pemanfaatan AIS terhadap kinerja individual. Survey yang dilakukan 
memberikan hasil sebesar $42,3 \%$ sampai $61,9 \%$ responden memberikan jawaban setuju atas semua item pertanyaan kemudahan penggunaan. Dengan kata lain sebagian besar responden menganggap penggunaan Academic Information System (AIS) adalah mudah.

Dari pengujian statistik, menunjukkan bahwa nilai koefisien regresi variabel moderating ternyata tidak signifikan yaitu dengan probabilitas signifikan 0,564 yang jauh di atas 0,05. Dengan kata lain, variabel moderating kemudahan pengguna tidak berpengaruh secara signifikan terhadap pemanfaatan AIS dan kinerja Individual. Hasil penelitian ini tidak mendukung teori Technology Acceptance Model (TAM) bahwa TAM berfokus pada sikap terhadap pemakai teknologi sistem informasi, dimana pemakai mengembangkannya berdasarkan persepsi manfaat dan kemudahan dalam pemakaian teknologi sistem informasi. Hasil uji hipotesis 2 tidak sejalan dengan penelitian Davis et al. (1989), Szajna (1996), Venkatesh dan Davis (2000), dan Venkatesh dan Morris (2000) (dalam Jogiyanto 2007) yang membuktikan bahwa kemudahan berpengaruh terhadap penggunaan sistem informasi baik secara langsung maupun tidak langsung. Demikian juga penelitian Iqbaria (1997) membuktikan bahwa kemudahan pemakaian dan kegunaannya mempunyai pengaruh terhadap penerimaan penggunaan PC di perusahaan kecil. Jika dibandingkan dengan penelitian sebelumnya terjadi perbedaan hasil penelitian yaitu pada variabel kemudahan pengguna yang mana pada penelitian ini kemudahan pengguna tidak berpengaruh secara signifikan. Dengan kata lain jika dihubungkan dengan penelitian sebelumnya dapat dikatakan tidak konsisten.

\section{SIMPULAN}

Pemanfaatan Academic Information System (AIS) berpengaruh positif secara signifikan terhadap kinerja individual. Kemudahan penggunaan ternyata tidak memoderasi pengaruh pemanfaatan Academic Information System (AIS) terhadap kinerja individual. Variabel kemudahan penggunaan bukan merupakan variabel moderating.

Survey yang dilakukan memberikan hasil sebesar 42,3\% sampai $61,9 \%$ responden memberikan jawaban setuju atas semua item pertanyaan 
kemudahan penggunaan. Dengan kata lain sebagian besar responden menganggap penggunaan Academic Information System (AIS) adalah mudah. Dari pengujian statistik, menunjukkan bahwa nilai koefisien regresi variabel moderating ternyata tidak signifikan yaitu dengan probabilitas signifikan 0,564 yang jauh di atas 0,05. Dengan kata lain, variabel moderating kemudahan pengguna tidak berpengaruh secara signifikan terhadap pemanfaatan AIS dan kinerja Individual.

\section{PUSTAKA ACUAN}

Darwin, R.N. 1999. Komputerisasi Pasar Swalayan: Implikasi Terhadap Kinerja Karyawan. (Tesis Tidak Dipublikasikan). Semarang: MAKSI UNDIP.

Davis, Fred D. 1989. Perceived Usefulness, Perceived Ease of Use and User Acceptance of Computer Technology. MIS Quertely, September 1989.

Davis, F.D. et.al. 1989. User Acceptance of Computer Technology : A Comparison of Two Theoritical Models. Management Sciences, August 1989.

Diana P.M. 2001. Studi Empiris Tentang Faktor-Faktor Yang Mempengaruhi Pemanfaatan Personal Computing dan Dampaknya Terhadap Kinerja Karyawan Akuntansi. (Tesis Tidak Dipublikasikan). Semarang: MAKSI UGM.

Ghozali, I. 2006. Aplikasi Analisis Multivariate Dengan Program SPSS. Semarang: Badan Penerbit UNDIP.

Goodhue, D.L. 1995. Understanding User Evaluation of Information Systems.. Management Sciences. December 1995.

Goodhue, D.L. \& R.L. Thompson. 1995. Task-Technology Fit and Individual Performance. MIS Quarterly (19:2). pp. 213-236.

Iqbaria, M. et.al. 1997. A Personal Computing Acceptance Factor on Small Firms: A Struktural Equation Model. MIS Quarterly, 21, 3, pp. 279302.

Jogiyanto. 2007. Sistem Informasi Keperilakuan. Yogyakarta: Andi. 
Jurnali. 2002. Analisis Pengaruh Faktor Kesesuaian Tugas-Teknologi dan Pemanfaatan Teknologi Informasi Terhadap Kinerja Akuntan Publik. Jurnal Ekonomi dan Bisnis.

Kurniawan, R. 2008. Analisis Pengaruh Teknologi Informasi Pada Kinerja Organisasi Study Empiris PT. Bank Rakyat Indonesia (PERSERO) Tbk Unit Kantor Cabang Tegal, Kantor Wilayah Semarang. (Tesis Tidak Diplubikasikan). Semarang: MAKSI UNDIP.

Nisfiannoor, M. 2009. Pendekatan Statistik Modern Untuk Ilmu Sosial. Jakarta: Salemba Humanika.

Sugiyono. 2008. Metode Penelitian Kuantitatif Kualitatif dan R\&D. Bandung : Alfabeta.

Sunarta, I.N. 2005. Analisis Faktor-Faktor Yang Mempengaruhi Pemanfaatan Teknologi Informasi dan Pengaruh Pemanfaatan Teknologi Informasi Terhadap Kinerja Individual. (Tesis Tidak Dipublikasikan). Semarang: MAKSI UNDIP.

Swanson, K. et.al. 1991. The Application Software Factory: Applying Total Quality Techniques to Systems Development. Management Information System, 15:4 (December). pp.567-579.

Szajna, B. \& W.S. Rizard. 1993. The Effect Of Information System User Expectation on Performance and Perception. MIS Quarterly.

Thompson, R.L. et.al. 1991. Personal Computing: Toward a Conceptual Model of Utilization. MIS Quartely, March 1991. 